\title{
ORGANIZATIONAL ENDOGENOUS DEVELOPMENT: THE MICRO-FOUNDATIONS, OPPORTUNITIES AND REAL OPTIONS PERSPECTIVE
}

The paper presents significantly salient issues in the field of strategic management in terms of organizational endogenous development understood as the concept integrating three areas. Consequently, the research questions of the paper are as follows: (1) Is it possible to describe a strategy of contemporary organizations assuming their endogenous development? (2) What constitutes the fundamentals of organizational endogenous development? and (3) How do those fundamentals affect organizational endogenous development? Hence the aim of the paper is to enrich the strategic management field and consequently to present the elements of the triad: socio-psychological managerial characteristics (predictors, SMC) - opportunities (O) - real options (RO) in terms of strategic management and to endeavour by the means of that triad, to answer the research questions. The method that has been used is extensive literature review, therefore inference is deductive. The first section presents opportunities as potential determinants of organizational endogenous development. The real options concept constituting the support for implementing opportunities approach has been described in the second section. Then, socio-psychological managerial characteristics as the micro-foundations of organizational endogenous development have been emphasized and presented. Finally, the conclusion with final remarks, limitations, and research directions has been presented.

Keywords: socio-psychological micro-foundations, opportunities, real options.

DOI: 10.15611 aoe.2017.1.03

\section{INTRODUCTION - PRELIMINARY ASSUMPTIONS}

Classic theory concerning a strategy in management science is based on the assumptions of bounded rationality theory that contemporarily do not have such a radical character as before. The changes are determined by nonlinear organizational growth and non-deterministic sources of strategic thinking. The assumptions constituting dogmas of strategic management previously such as: a) strategic decisions are made rationally, b) a manager is able to create and implement a strategy without managerial illusion, c) organizational environment is predictable, d) a strategy is a formalized longterm plan of actions, e) a strategy is based on the greatest possible amount of

\footnotetext{
* Department of Strategy and Management Methods, Wroclaw University of Economics
} 
information, nowadays seem to have become obsolete (e.g. Henzler 1982; Campbell 1998; Sułkowski 2013).

The classic assumptions, mainly of a planning school, a positional one, and a resource-based view, should be revisited, especially in the context of the decreasing efficiency of contemporary strategic management (Obłój et al. 2010). Empirical results of the research conducted in $2010-2012^{1}$ in Polish enterprises from the telecommunication sector indicate that a classic strategy is in the form of a formal document that in reality is only information for the organization's stakeholders about the vague future and is one of the important factors motivating employees (Sus 2012, pp. 40-43; Sus 2013, pp. 50-53). Therefore, it is worth considering whether sectors other than telecommunication also make decisions on the basis of current information shifting from long-term planning to an analysis of short periods of time. Big companies planning their activities do that inefficiently and the mistakes resulting from such activities are not caused by a lack of knowledge of planners or forecasters, rather by the lack of possibilities of predicting the future (Mankins and Steele 2006). If there are no possibilities of anticipating changes in environment, it might be wondered whether an organization could take such internally flexible forms that would allow active responses to the changes.

The approach proposed in the paper is concentrated on organizational endogenous development understood as the concept integrating three endogenous areas that, according to the authors' opinion, constitute the necessary determinants of effective strategic planning. Consequently, the research questions of the paper are as follows:

(1) Is it possible to describe a strategy of contemporary organizations assuming their endogenous development? (2) What constitutes the fundamentals of organizational endogenous development? and (3) How do those fundamentals affect organizational endogenous development?

Hence the aim of the paper is to enrich the strategic management field and consequently to present the elements of the triad: socio-psychological managerial characteristics (predictors, SMC) - opportunities (O) - real options (RO) in terms of strategic management and to endeavour by means of that triad to answer the research questions.

Specifying and linking these three research realms seems to be original and might contribute to developing empirical studies in the field of

\footnotetext{
${ }^{1}$ Empirical research was financed from public funds for science in $2010-2012$ as an own research project (Sus A.) no. N N115 021239.
} 
organizational endogenous development. While managerial individual predictors were considered in many studies with regard to making decisions (e.g. Greve 2013), strategic problem formulation (e.g. Baer et al. 2013), innovativeness (e.g. Nooteboom and Stam 2008), entrepreneurship (e.g. Bryant 2014), and others, they were not taken into consideration in the triad influencing organizational endogenous development as a proposed dependent variable concerning an organization's strategic growth on the basis of non-product-market categories, only exogenous changes like opportunities. In turn, opportunities have been envisaged as some events (e.g. competitor's failure) or a unique confluence of circumstances (e.g. market niche development) enhancing the possibilities of achieving extraordinary advantages. Consequently, it determines the mechanism of analysing opportunities and incorporating, for instance, the real options tool so as to reveal the events that might constitute new opportunities in the future which may generate the process of searching for opportunities creatively while simultaneously changing the way of perceiving the environment.

Hence, organizational endogenous development is expected to be a result of some independent variables, namely managerial socio-psychological predictors like selected social attitudes (conformity vs. non (anti)conformity, individualism $v s$. collectivism, proactivity $v s$. reactivity) as well as selected psychological traits (proactive personality traits, temperament, character, and resistance to risk and organizational stress resilience) influencing managerial behaviour in terms of seeking and using opportunities (on the basis of implementing, for instance, the real options approach) constituting the fundamental of organizational endogenous development. Additionally, it has been assumed that the process is enhanced or hindered with the moderator - managerial affective commitment.

The measure of the organizational endogenous development in a given triad might be the number of opportunities resulting in the organizational growth capability in the following fields: a) financial (e.g. revenues from sales, production and sales volume, new products share in operating revenues, or market share), b) technical-organizational (e.g. R\&D expenditure, implemented innovations, new partnership relationships), and c) social (e.g. employee and customer satisfaction, or employment stability). The proposed tool is the Total Performance Scorecard (Rampersad 2002), taking into account the continuous improvement of individual and organizational results. Admittedly, the focus on individual performance with regard to managerial socio-psychological predictors might help evaluate organizational endogenous development. 
The paper is embedded around the edges of various schools and thoughts of strategic management. Due to Obłój's classification of strategic management schools (Obłój 2007), in which the criterion of grouping is decisional freedom and formalization of strategy, the categories considered in the paper could be assigned to the school of resources (especially intangible ones), skills, and learning; simple rules, opportunities as well as real options. Indeed, Obłój, as the only one amongst researchers in the field of strategic management, has considered real options as a separate school of strategic management since he perceived the potential and non-doubtful advantages of that concept for contemporary organizations.

The paper is based on theoretical considerations and available conceptual and empirical studies in terms of the characteristics of strategy schools. Hence, the inference is deductive.

The paper is organized as follows. The first section presents opportunities as potential determinants of organizational endogenous development. The real options concept constituting the support for opportunities approach implementation is described in the second section. Then, sociopsychological managerial characteristics as the micro-foundations of organizational endogenous development are emphasized and presented. Finally, the conclusion with final remarks, limitations, and research directions is presented.

\section{OPPORTUNITIES AS DETERMINANTS OF ORGANIZATIONAL ENDOGENOUS DEVELOPMENT}

The category of opportunities, although crucial for strategic management mainly due to an important pathway to change in organizations (Duton 1993), is not unambiguously understood in the literature studies since they can be identified with possibilities, chances, and just opportunities. Specifying and explicitly distinguishing an 'opportunity' notion from a 'chance' as well as the relativity of these categories constitute significant dilemmas in the strategic management field. Opportunities are strictly connected with a particular moment of time and period. They appear, last, and disappear both in the environment and inside the enterprise. Moreover, the primary opportunities are themselves spatial and temporal units and space-time itself is simply their 'relatedness' characterized presumably in terms of a suitable pattern. Consequently, a whole chain of primary opportunities related serially by the relation of immediate causation constitutes a causal chain of opportunities (Martin 1974, p. 101). Although it might be thought about the subjectivity of 
identifying opportunities (e.g. Skat-Rørdam 1999), those coming from the general environment undoubtedly have a wider and more common scope and they last longer (e.g. law regulations supporting the growth of organizations) as well as they do not generate competitive circumstances (e.g. tax resolutions and acts). The opportunities coming from the close environment are more subjectively perceived, they appear suddenly, they last shorter as they usually have a competitive character, e.g. a tender (Krupski 2007). Additionally, the capability of evaluating opportunity's attractiveness with regard to the potential tangible and intangible advantages for the enterprise plays a pivotal role (Krupski 2007).

Classic theory of organization and management undoubtedly exposed planning as one of the basic tasks of management. Planning, including defining goals and ways of achieving them, was the will of creating reality with the imperative of implementing. However, classic organization and management science was developed in conditions of a well-structured and predictable environment. The increase of environmental turbulence has contributed to the situation that current management theory does not describe enough the conditions of making decisions resulting in a longer time and it does not propose new organizational behaviour, excluding an evolutionary approach to organizational change (e.g. Stańczyk-Hugiet 2015).

A plan, especially, a long-term strategic one, is in contra-position to the flexible behaviour of an organization that is contemporarily desired. According to the research described by Skat-Rørdam (1999), opportunities are becoming more and more important to an enterprise's growth. Arguably, Collins and Porras (2000) have justified that in some of the biggest American corporations corporate strategies were based on opportunities. When it comes to the state of the art in the realm of opportunities in Poland, in 2004 R. Krupski began the research in terms of using opportunities by contemporary Polish organizations. The main purposes of the research were: a) to establish whether Polish enterprises are flexible and indirectly whether they have the potential for using opportunities, b) to establish the scale of enterprises' growth through opportunities, and c) to identify the types of resources necessary for using opportunities. In attaining the first aim, an original method of examining flexibility of enterprises based on a multidimensional analysis was proposed and the following assessment criteria were assumed (Krupski 2005d): a) product innovation, b) cooperation and partnership, c) internalization and diversification of activities, d) decentralization of decisions/the speed of making decisions, e) observing customers and competitors, f) the attempts to gain new customers, 
the attempts to enter new markets, g) training and general educational activities of employees, f) access to own or foreign financial assets. Using this method, the flexibility of 180 enterprises was explored (Krupski 2005c). It was found that $51 \%$ of the sample constituted enterprises with an average level of flexibility, $41 \%$ of the sample constituted enterprises with a high level of flexibility. It was also evidenced that among big companies, the companies with a low level of flexibility were not found. Amongst factors decreasing the flexibility of enterprises only one was independent of the enterprise's size-limited access to own or foreign financial assets.

The second research stream concerned the essence and importance of opportunities in the enterprises' growth. On the one hand, an opportunity in the context of expected value was defined (using probability). A particular structure of an opportunity life cycle was proposed (Krupski 2005b). On the other hand, the scale of the opportunities' impact on the directions of companies' growth was studied. One hundred and fifty-five medium, small and micro-companies were surveyed. On the basis of 83 enterprises (54\%), it was shown that a coincidence with characteristics of an opportunity decided about their growth. According to the research, 10 types of opportunities were distinguished (Krupski 2005a): (a) extremely cheap, unplanned purchase of the means of production, place, buildings, etc., (b) unexpected cooperation offers from a big known company, (c) using various European Union's funds, (d) new favourable system solutions, (e) buyout of bankrupt competitors, (f) withdrawal from the market of a local competitor and a merger of its customers, (g) gaining a new investor, joining enterprises, (h) eliminating failures, (i) unexpected winning of tender, and (j) unexpected increase of demand from general environment.

The following development results of identified opportunities for surveyed enterprises were also determined: a) significant sales increase within current activities, b) concentric diversification, c) conglomerate diversification, d) a totally new domain (product and market) with liquidating current activities. The research results were as follows: In 50\% of the surveyed companies a coincidence determined the enterprise growth. The companies used different arising opportunities so as to increase sales within current activities and to enter new markets. They also took the risk of introducing new domains in some cases not having any connection with current activities. Most of the opportunities were connected with the unplanned purchase of means of production, place, buildings with attractive prices. More than half of the enterprises launched new activities without any connection with current activities. The other types of opportunities either 
were connected with a sales increase in the scope of current activities on the same or similar markets or introducing related domains.

The next research stream constituted the problem of resources in two following contexts: the context of organizational flexibility exemplified by organization potential in using opportunities, and the context the features of Barney's resources on which organization strategies should be built. One hundred and fifty-one medium, small and micro-companies were surveyed. The subject of research were resources recognized as at least relatively original in enterprises in the scale of sectors (Krupski 2006a). As for resources importance in using opportunities, respondents picked three from all the eleven researched resources. The general research results were as follows (Krupski 2006b): The most important resources for using opportunities were: privileged not formalized relationships with environment (107 indications), knowledge, skills, and employees' talents (81 indications), and IT (63 indications). Privileged not-formalized relationships were chosen as the most important resource (in the context of flexibility, the use of opportunities) independently of the enterprise size. Knowledge was chosen mainly by the representatives of big, medium, and small enterprises (not micro ones). From micro-enterprises the location was the most important resource. Small and medium sized enterprises treated IT as one of the most important resources for using opportunities.

As a result, taking into account the considerations aforementioned, the following proposition has been formulated:

Proposition 1 (P1): The capability of seeking and using opportunities is positively associated with organizational endogenous development.

Nonetheless, it is required to apply some stable necessary characteristics of the process of using opportunities, which determine organizational endogenous development, for instance, a) the ability to precisely analyse the environment areas in which opportunities appear irrespective of their content and potential, b) the ability to gather information about the attributes of opportunities, and c) the ability to evaluate the expected value of opportunities by means of either statistical methods or logic inferring (Krupski 2007).

The mechanisms of identifying and using opportunities have long been examined, however, the abilities aforementioned refer to the necessity of working out a permanent mechanism of analysing cause-and-effect relationships between opportunities and their consequences. The approach that might contribute to such an analysis and widen strategic management in the field of opportunities and organizational endogenous development is the real options philosophy. 


\section{REAL OPTIONS AS THE TOOL SUPPORTING OPPORTUNITIES APPROACH IMPLEMENTATION}

A real options approach in the context of making strategic decisions was widely described in the literature (Amram and Kulatilaka 1999; Bowman and Moskowitz 2001; Copeland and Keenan 1998 (a,b); Leslie and Michaels 1997; Miller and Waller 2003; Mun 2006; Triantis and Borison 2001; Trigeorgis 1993; Trigeorgis 1999; Zeng and Zhang, 2010), however, this concept is not generally used in practice by contemporary enterprises. This approach, amongst current tools of strategic planning, is connected with the greatest possibilities of predicting the future as well as of reacting in real time to environmental changes which determines an organization's existence and growth.

Real options constitute a possibility, not an obligation, to take a particular action (Copeland and Keenan 1998a, 1998b), in contrast to financial options that were an inspiration to apply this approach in strategic management (Myers 1977). Consequently, real options are connected with some, not obligatory, activities that might be realized by an enterprise in real time $t_{0}$. The possibilities are identified by an enterprise in the environment and constitute new, endogenous managers' competences of contemporary organizations. This means that they are able to use sudden situations that at a given moment are the most useful for a company and they are assessed on the basis of internal and external sources of information (Wang et al. 2003, p. 54). Additionally, an enterprise constantly monitors the environment which contradicts the classic principles of strategic planning. Organizations, by means of real options, are more sensitive to changes of the configuration of external environmental elements which then leads to changes of internal organizational resources and to active reaction to opportunities.

The condition that determines opportunities and the incorporation of real options approach is uncertainty since the more uncertain the bigger the value of options (Copeland and Keenan 1998(a), p. 41). Only under conditions of high risk (the risk understood as measureable uncertainty) the identification of various activities' alternatives is rational. A decision-maker is conscious of functioning under uncertain conditions and tries to consider the chances of the particular decisions and the mutual relationships amongst them. Paradoxically, uncertain conditions influencing making decisions constitute the fact and reality of contemporary enterprises which enhances the 
usefulness of the proposal presented. Nevertheless, the real options approach is not frequently used in practice. Triantis and Borison (2001) conducted empirical research concerning the usage of real options concept in practice. The research was conducted in thirty-four enterprises from seven different sectors. The respondents were top managers and middle managers from the following areas: risk management, finance, strategic management, marketing, and research and development. The surveyed enterprises that have used the concept of real options in practice have several such mutual features (Triantis and Borison 2001, p. 9):

- they operate in sectors with high investment expenditures and high uncertainty of return on investment (a biotechnological sector);

- in most cases they operate in sectors with big structural changes therefore traditional methods of evaluation are not enough (an energetic sector);

- most enterprises are from engineering-driven sectors (pharmaceutical sector, IT sector), few enterprises from finance-driven sectors (banks, insurance companies) were interested in using real options.

The research was based on three core questions (Triantis and Borison 2001, p. 9):

1. What were the reasons for implementing real options in the enterprise?

2. How and where were real options implemented?

3. What are the key success factors in the process of implementing real options?

Most of the respondents perceived the application of real options as dramatic departure from the past that enabled them to effectively manage strategic risk, to eliminate competitors, to reveal new possibilities of growth, to use chances as well as to maintain their current position on the market. The other enterprises treated real options as a revolutionary solution of business problems in contrast to the evolutionary process of rationalizing the investment valuation and capital allocation that result in increasing the value for stockholders. In these cases it was not necessary to use real options, however they were used due to potential advantages (Triantis and Borison 2001, p. 9).

The ways of implementing real options in the enterprises surveyed were different as well. Real options were implemented as (Triantis and Borison 2001, p. 10):

- a way of thinking and language for the benefit of constructive communication in solving decisional problems; 
- an analytical tool allowing to evaluate the performance with the value of both the performance's flexibility and future growth possibilities (using the theory of financial options evaluation);

- an organizational process in which options are understood as part of a bigger strategic process, as a management tool used for identifying and exemplifying a strategy.

Real options as a way of thinking allow to order complex investment projects. Perceiving investments through options that might be realized, purchased, sold, etc. allows to eliminate various sources of uncertainty and to influence the effectiveness of activities realized. In such cases there is always a particular solution that allows to limit potential losses. This way of functioning also helps to appreciate the role of learning and obtaining information and competences that are necessary to realize the decision made or to identify options that will lead an activity to a particular direction. As a way of thinking, real options impose unambiguous language that positively influences internal and external communication in an enterprise (Ziarkowski 2004, p. 85).

Nevertheless, using real options in the form of an analytical tool creates many problems connected with: a) measuring options, b) a lack of competences, and c) the lack of managerial conviction about the correctness of methods used for evaluating options (Miller and Waller 2003, p. 98). Moreover, many problems are associated with the complicated mathematical tool. The method of discounting cash flows, especially NPV, generates difficulties in forecasting future cash flows even at the first stage. During the identification of different scenarios of developing an activity it is impossible to dynamically plan inflows and outflows connected with an investment as they depend on decisions that will be made in the future - while the latter depend on the level and quality of the available information. In the case of an investment in which many such decisions occur, it becomes impossible to present an investment project in an interactive way. A solution for such a problem is to present an investment project in the form of a decisional tree that allows to structure a project and determine all the important decisional moments (Ziarkowski 2004, pp. 87-88). Due to this approach, decisions made by managers require the features of flexibility. Nonetheless, despite some key success factors resulting from implementing the real options approach (e.g. Triantis and Borison 2001), a few enterprises incorporate that tool, which seems quite intriguing. Admittedly, according to the results of a survey conducted in 2000 by the consulting company Bain \& Co. about the popularity of the 25 main strategic methods, the real options approach was 
assessed as one of the least popular. In 2003 the survey was conducted once again by the same company without the real options tool in the list for ranking (Obłój 2007). The reasons for so low an interest in the real options' approach seem to be the methods of investment effectiveness valuation unknown by managers. It seems that the concept of real options should be associated not only with a complicated mathematical tool, but also with the management philosophy based on actively analysing the course of realized activities, on a flexible choice of identified alternatives of actions as well as with a dynamic mechanism of identifying opportunities having been analysed.

Concluding, it is worth mentioning that real options as a tool of management might be a source of many advantages for an enterprise. First, they enhance the process of making strategic decisions and give them a dynamic and interdisciplinary character. In the process of realizing options, teams have to realize stages of gathering data, analysing data, and presenting results. Secondly, real options emphasize particular value for shareholders as opposed to such measures as production volume, income, or market size. Thirdly, they highlight the dynamics of organizational learning. Finally, they changed the analytical tools constituting the base of the process of evaluating options (Triantis and Borison 2001, p. 17).

As for the factors making the real options approach difficult to be implemented, it seems that emphasizing its role in identifying opportunities might promote it as an innovative approach in the field of strategic planning the endogenous success factors of contemporary organizations. It seems that connecting practical and empirical perspectives of a rarely used real options' approach in the form of an analytical tool, and becoming management philosophy, as well as taking into consideration the increasing importance of using opportunities in the process of generating organizational performance, the value added for contemporary enterprises might appear. In that way, actively using opportunities and maximizing decisional flexibility of managers becomes possible.

The abilities to analyse both opportunities and their consequences in the form of a set of options determine the necessary characteristics of the aforementioned opportunities. As a result, a system of early recognition occurs and is incorporated in the process of strategic planning (compare Ansoff $(1976,2007)$ and his weak signals theory as well as Ansoff and McDonnell, 1990).

The premise and essence of the early recognition system referring to the opportunities and real options approaches are illustrated in Figure 1. 


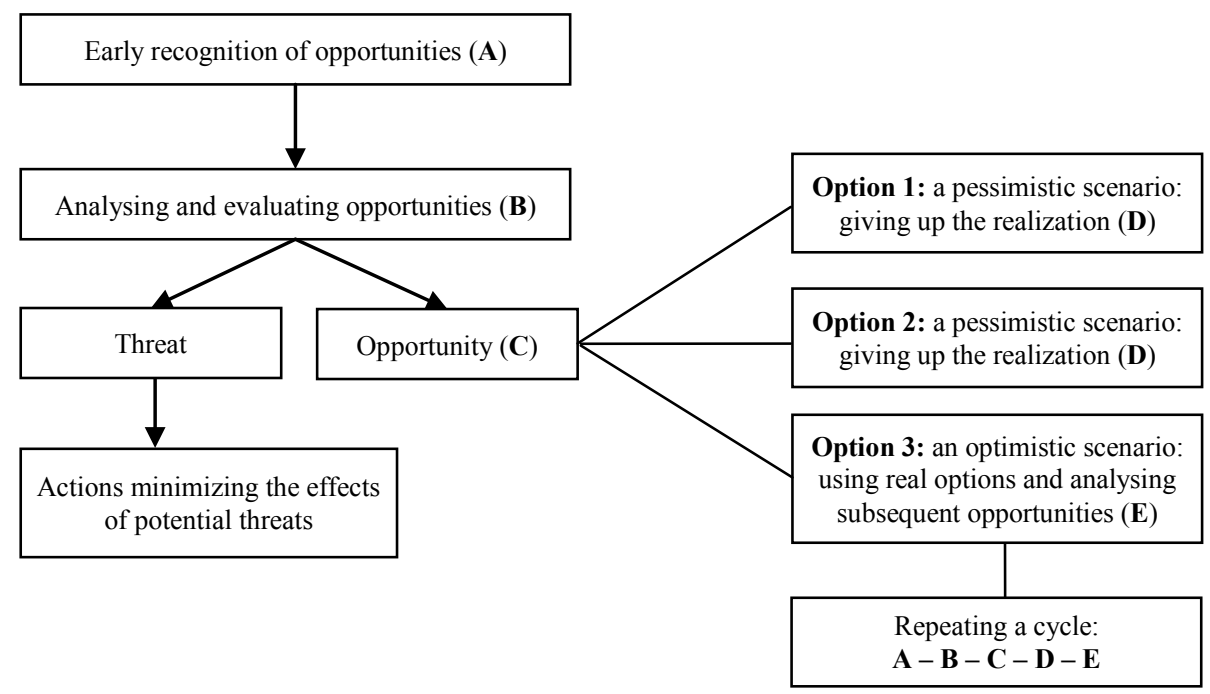

Figure 1. A cycle of early recognition of opportunities with real options approach applied

Source: own study (Sus A.)

Consequently, the following proposition has been formulated:

Proposition 2 (P2): Real options approach might facilitate seeking and using opportunities in organizations.

This facilitation might be ensured through analysing a) threats and their consequences supporting risk management in organizations (this approach is not covered by our paper), and b) opportunities supported with real options methods including the evaluation of expected value and organizational flexibility in accordance with the following equation (Trigeorgis 1993, p. 2):

$$
\text { Extended NPV = static NPV + flexibility value. }
$$

According to the classic approach, the added value of investments have constituted the criterion of selecting ex ante a particular strategic decision on the basis of the time $t=0$ in the form of net discounted present value (NPV). In turn, real options enable to select many possibilities with their extended net discounted present value at subsequent strategic project stages $(t=1$, $t=2, t=3$, etc.) (Obłój 2007, p. 181). Assuming that a decision maker disposes of $m$ scenarios for each time period with the probability $p_{k}\left(\forall_{j} \sum_{j} p_{k, j}=1\right)$, there is a set of possible $N P V_{T}$, in accordance with the following equation (Krupski and Sus-Januchowska 2009): 


$$
N P V P_{t}=\sum_{t=1}^{T} \frac{p_{t}\left(C_{t}-I_{t}\right)}{(1+r)^{t}},
$$

where: $p_{t}$ - probability of selecting a particular scenario; $C_{t}-$ revenues at time $t^{2} ; I_{t}$ - expenditures at the time $t ; r$-discount rate; $t$ - the time of realizing a given project (counted in the periods of variable discount rates).

Hence it is possible to define an optimal set of choices, e.g. $\left\{\mathrm{W}_{1}\left(\mathrm{t}_{1}\right), \mathrm{W}_{5}\left(\mathrm{t}_{2}\right), \mathrm{W}_{5}\left(\mathrm{t}_{3}\right), \mathrm{W}_{2}\left(\mathrm{t}_{4}\right)\right\}$, whose $N P V$ meets the maximising criterion. Consequently, options are used dynamically on the basis of current probabilities and expected values. A manager disposes revenues and costs at each time stage. The process is proceeded in a cycle (Figure 1).

Concluding, real options facilitate evaluation of future undertaking's value as well as harmonizing managerial activities in terms of timing (Miller and Waller 2003, p. 98).

Focusing on opportunities activates the dynamics of managers' strategic decisions, however not all managers possess the same personal characteristics. Consequently, the knowledge about which micro-foundations ought to describe strategic activities in terms of endogenous organizational development is salient.

\section{SOCIO-PSYCHOLOGICAL MANAGERIAL CHARACTERISTICS AS THE MICRO-FOUNDATIONS OF ORGANIZATIONAL ENDOGENOUS DEVELOPMENT ${ }^{3}$}

One of the underpinnings of enterprise's management philosophy based on seeking and using opportunities ought to be oriented towards accurate managerial adjustment to the specific organizational profile. Such an adjustment, embedded in the strategic management field, especially in a behavioural strategy concept and micro-foundations approach (e.g. Piórkowska 2014), might be analysed from the perspective of particular social attitudes (e.g. Piórkowska 2012, 2013, 2016a; Piórkowska and Niemczyk 2013; Stańczyk-Hugiet et al. 2015) revealing the social aspect of

\footnotetext{
${ }^{2}$ In the case of an optional project financial flows constitute the following equation: revenues + extraordinary profits - operating costs - investment costs - amortisation costs extraordinary losses.

${ }^{3}$ This part of the paper is solely authored by K. Piórkowska as well as strictly connected with realizing the project financed by the National Scientific Centre in Poland on the basis of the decision no. DEC-2012/05/D/HS4/01317.
} 
micro-foundations as well as particular psychological features (especially, temperament, character, personality, resistance to risk and stress, affective organizational commitment) (e.g. Piórkowska 2014) reflecting the psychological side of developing a behavioural strategy in enterprises.

\subsection{Selected managerial social attitudes and organizational endogenous development}

Not only has mainstream economics increasingly started valuing the role of social attitudes in the outcomes (Munasib and Roy 2008), and also behavioural economics (e.g. Gigerenzer and Selten 2002; Kahneman 2003, 2011) as well as organization and management science - particularly in organization's both financial and non-financial performance (e.g. Boal and Hooijberg 2001; Finkelstein and Hambrick 1996).

Social attitudes, as the reflection of social psychology phenomena individualisation (Farr 1994), which assumes inter alia that social interactions involves ex ante potential for heterogeneity in both individual and social attitudes, constitute a kind of widely understood individuals' attitudes that refer to feelings, moods, and another internal experience (Hall et al. 1998). A meaningful hallmark of both individual and social attitude is its evaluative character and the evaluation might be treated as cognitive (emotionally neutral evaluation), affective (feeling towards an attitudinal object) or behavioural (tendency to behave in a particular way towards an attitudinal object) (e.g. Makin et al. 2000, p. 79, Robbins, Coulter 2005, p. 344). Considering that phenomenon, it has been envisaged that the following managerial social attitudes potentially directly or indirectly influence the abilities to seek and use opportunities through implementing proper instruments and consequently organizational endogenous development: conformity versus non-conformity (anti-conformity or counter-conformity), individualism versus collectivism, and indifferentism (reactivity) versus proactivity.

Conformity vs. non (anti) conformity and organizational endogenous development. The research on conformity originally comes from the work and research of Asch (1951, 1956), Sherif (1935), (focusing on autokinetic effect and informational influence), as well as Deutsch and Gerard (1955), and concerns analysing the influence of the pressure on an individual exerted so as to adjust to the expectations of others (the leader, the group, society, organization). Specifically, social conformity is defined as the tendencies of members of a society to manifest the communality of attitudes and of 
behaviour as a result of the restrictive influences of culture and society on personality development the following determinant areas of social conformity are also valid: moral values, positive goals, reality testing, ability to give affection, tension level, and impulsivity (Bernberg 1954, p. 148; Bernberg 1955). Moreover, Deutsch and Gerard (1955) distinguished informational and normative central motivation of conformity. Informational motivation of conformity (informational influence) refers to the desire of appropriate interpretation of reality and proper behaviour in the context of accurate tasks' performance (the lack of objective information causes the reference to be embedded in the group's norms). In contrast, normative motivation of conformity is connected with meeting affiliation needs and obtaining the approval of others in order to avoid exclusion (normative influence). Hornsey et al. (2003, pp. 4-5) think that informational influence of conformity is internalized by a person and leads to changing the authentic attitude, however, normative influence does not implicate changing the authentic attitude, despite the efforts of the person in order to be accepted and to avoid exclusion. In general, non-conformity is revealed in either the form of constructive non-conformity (the objection is reasonable) or destructive one, called anti-conformity (or counter-conformity), revealing automatic resistance to the expectations of others.

Since implementing opportunities' approach requires brave managerial attitudes transferred into mostly non-standard behaviour (e.g. Ajzen 2005), conformist or non-conformist/anti-conformist attitudes might determine the character of the organizational strategy (behavioural strategy) in the context of endogenous development on the basis of seeking and using opportunities. Consequently, the following propositions have been formulated:

Proposition 3a (P3a): The low level of conformity (in terms of both informational and normative influence) is positively associated with the capability of seeking and using opportunities in organizations.

Proposition $3 b(\mathrm{P} 3 b)$ : The high level of both non-conformity and anticonformity is positively associated with the capability of seeking and using opportunities in organizations.

Proposition 3c (P3c): The capability of seeking and using opportunities in organizations constitutes the mediating effect on the relationship between managerial conformity (both informational and normative influence), nonconformity/anti-conformity and organizational endogenous development.

The conformity construct can be measured using behavioural observations (used vary rarely due to time consuming and other obstacles), laboratory experiments (e.g. Asch 1951, 1955, 1957), simulations (e.g. Lee 
2006; Lee and Nass 2002; Sassenberg and Boos 2003) and, recently much more frequently, self-monitoring and self-reports (e.g. Goldsmith et al. 2005; Levine 2004; Rudman and Fairchild 2004).

In the present study it is proposed to incorporate the valid and reliable Lennox and Wolfe's (1984) Revised Self-Monitoring Scale (RSMS) to measure behavioural conformity. The RSMS consists of 13 items measured on a 6-point Likert-type scale. Seven of these items represent Ability to Modify Self-Presentation (an exemplary item is: 'I have the ability to control the way I come across to people, depending on the impression I wish to give them'). The other six items represent Sensitivity to the Expressive Behaviours of Others an exemplary item is: 'I can usually tell when I've said something inappropriate by reading it in the listener's eyes'). According to the nonconformity and anti-conformity measurement tools, it is suggested using respectively the Weissman and Paykel's Social Adjustment Scale interview (1974) and Willis's scale (1963) viewing conformity, independence, and anti-conformity as the vertices of a triangle, which allows for separate measurement of these dimensions.

Individualism vs. collectivism and organizational endogenous development. Individualism as a social attitude promoting the salience of individuals is contrasted to collectivism (compare Piórkowska 2016a). According to studies in that field, the theoretical considerations and the research results concern a cultural context, in which these categories are treated as dimensions or characteristics of culture (international or organizational context). In the paper, individualism and collectivism are considered from the individual's perspective (as a social attitude) despite the limitation that such attitudes might be changeable and complementary depending on the situational cues and environmental conditions. According to Triandis's understanding of individualism and collectivism (Triandis $1990,1995,1995 \mathrm{a})$ that has been demonstrated in the paper, the social behaviour of persons with individualistic features, contrary to those with collectivistic ones, is mainly determined by personal goals and in the case of the conflict between personal and group goals, prioritizing personal goals over group ones is acceptable.

While a collectivist attitude and behaviour make team/group goals prioritized, the specific focus on environmental context and cues, required within applying an opportunities perspective in the enterprise, involves very attentive and mindful individuals with their particular interests as the most salient (e.g. Langer 1997; Piórkowska 2016b; Weick and Sutcliffe 2001; Weick et al. 1999) which hinders the role of collectivist attitudes in favour of 
individualist ones. Hence, individualist and collectivist attitudes could determine the character of the organizational strategy in the context of endogenous development on the basis of seeking and using opportunities. Consequently, the following propositions have been formulated:

Proposition 4a (P4a): An individualist managerial attitude is positively associated with the capability of seeking and using opportunities in organizations.

Proposition 4b (P4b): A collectivist managerial attitude is negatively associated with the capability of seeking and using opportunities in organizations.

Proposition 4c (P4c): The capability of seeking and using opportunities in organizations constitutes the mediating effect on the relationship between managerial individualist and collectivist attitudes, and organizational endogenous development.

Considering the measurement tool applicable to examine both individualist and collectivist attitudes, Triandis and Gelfland's scale (1998) is proposed to be incorporated. The scale measures consisting of 16 items (9point scale) is designed to measure four dimensions of collectivism and individualism: (1) vertical collectivism - perceiving the self as a part of a collective and being willing to accept hierarchy and inequality within that collective (an exemplary item: 'It is important to me that I respect the decisions made by my groups'), (2) vertical individualism - perceiving the self as fully autonomous, yet recognizing the inequality amongst individuals leads to accept that collective (an exemplary item: 'It is important that I do my job better than others'), (3) horizontal collectivism - perceiving the self as part of a collective, yet perceiving all the members of that collective as equal collective (an exemplary item: 'I feel good when I cooperate with others'), and (4) horizontal individualism - perceiving the self as fully autonomous, and believing that equality between individuals is the ideal situation collective (an exemplary item: 'My personal identity, independent of others, is very important to me').

Proactivity vs. reactivity (indifferentism) and organizational endogenous development. Taking into account the fact that the association of proactivity behaviour with endogenous constructs was evidenced (Seibert et al. 1999), it has been assumed in the paper that the proactivity phenomenon, which generally could be considered at three epistemological and methodological levels: a person, a team, an organization (Parker et al. 2006, p. 636), constitutes an individual social attitude leading a person to actively improve life quality and environmental context not responding to 
the past as well as to attain ambitious goals (Schwarzer 1999). Crant (2000) defines proactive behaviour as taking the initiative in improving current circumstances or creating new ones; it involves challenging the status quo rather than passively adapting to present conditions. Thus, reactive persons are passive and they rather tend, if ever, to adapt to the context and environmental cues than to change them. Moreover, a key constituent of proactive behaviour, as a result of a proactive attitude, is recognizing opportunities including those overlooked by others.

Admittedly, searching for opportunities requires the individual to proactively scan the environment through the indirect adjustment of her/his capabilities to the contextual factors (e.g. DuBrin 2013, p. 113). Indeed, while a reactive individual, being constrained by their environment instead of shaping it, waits until being asked or until it is absolutely necessary to gather information or make a decision, a proactive one, who is changeoriented and interested in creating a meaningful impact on the environment, engages in decision making and information gathering whenever possible which makes an organization able to have more appropriate strategic response with the intention of having a discernible effect on itself and/or the environment (compare Bateman and Crant 1993; Buss 1987; Diener et al. 1984; Grant and Ashford 2008; Lin and Carley 1993; Siebert and Kunz 2016). The proactive-reactive characteristics of managers therefore might determine the character of the organizational strategy (behavioural strategy) in the context of endogenous development on the basis of seeking and using opportunities. Consequently, the following propositions have been formulated:

Proposition 5a (P5a): A proactive managerial attitude is positively associated with the capability of seeking and using opportunities in organizations.

Proposition 5b (P5b): A reactive managerial attitude is negatively associated with the capability of seeking and using opportunities in organizations.

Proposition 5c (P5c): The capability of seeking and using opportunities in organizations constitutes the mediating effect on the relationship between managerial proactive and reactive attitudes, and organizational endogenous development.

Different measures of proactivity have been developed depending on the proactivity concept, namely either proactive personality, attitude or behaviour. According to the proactive attitude and behaviour required in the process of seeking opportunities that are manly context-dependent, it is 
proposed to incorporate Parker et al.'s (2006) proactivity measure based on scenarios - a context-specific approach. As for that measurement tool, the proactive work behaviour is understood as proactive idea implementation and proactive problem solving resulting from inter alia change and flexible role orientation.

\subsection{Selected psychological predictors and organizational endogenous development}

Although the ascertainment that managerial individual characteristics play a pivotal role in creating organizational performance, researchers have recently raised attention and concerns that micro-foundations of inter alia strategy and performance need much more wider investigation (e.g. Felin and Foss 2005, 2011). Accurate managerial adjustment to the specific organizational profile involving the organizational endogenous development approach is also associated with some psychological predictors such as proactive personality, temperament, character, resistance to organizational stress, and affective commitment.

\section{Managerial proactive personality traits and organizational endogenous development.}

Undoubtedly, human attitudes and behaviour are determined by personality, especially so-called central traits (e.g. Gastil 1961; Higgins 2000; Pervin 1989). As for Allport (1937), who catalogued 50 distinct meanings of the personality concept and contributed to the latter distinction of three views of personality attributes (namely, realist, constructivist, and functionalist), personality constitutes the dynamic organization within the individual of those psychophysical systems that determine their unique adjustments to their environment. In accordance with personality traits, they reveal relatively stable, consistent, and enduring internal characteristics that are inferred from the pattern of behaviour, attitudes, feelings, and habits in the individual (VandenBos 2007). One of the personality categories assigned to the aforementioned attitudes, especially proactive attitude and behaviour, is proactive personality rooted in the interactionist perspective (e.g. Bandura 1997).

This construct, understood as a proactive disposition revealing the tendency to initiate and maintain actions that directly alter the surrounding environment, differs ontologically from affective traits like well-being and from cognitive traits like locus of control and directly refers to identifying opportunities and acting on them (Bateman and Crant 1993; Crant 1996). Hence, proactive personality traits might determine the character of the 
organizational strategy (behavioural strategy) in the context of endogenous development on the basis of seeking and using opportunities. Consequently, the following propositions have been formulated:

Proposition 6a (P6a): The high level of proactive personality is positively associated with the capability of seeking and using opportunities in organizations.

Proposition 6b (P6b): The capability of seeking and using opportunities in organizations constitutes the mediating effect on the relationship between managerial proactive personality traits and organizational endogenous development.

According to the measure of the proactive personality, it is suggested using Bateman and Crant's (1993) scale (17 items) identifying a personal disposition toward proactive behaviour and differences among people in the extent to which they take action to influence their environment. An exemplary item is 'No matter what the odds, if I believe in something I will make it happen'.

Managerial temperament and organizational endogenous development. One scholarly view about temperament refers to the assumption that personality comprises of temperament and character, where temperament refers to emotional predispositions connected with genetic endowment and character is associated with more intentional goals and values that develop from environmental and social learning (Cloninger and Svracik 1997; Cloninger et al. 1993; Rothbart et al. 2000). Indeed, Cloninger's (1994) psychobiological model of personality encompasses hereditary temperament and environmentally determined character. Specifically, temperament as an element that creates personality means dispositions strictly connected with biological and physiological determinants. Temperament as a disposition or a trait ${ }^{4}$ constitutes an affective style of an individual. In turn, temperamental features (personality disposition) predispose a person towards experiencing a given emotional reaction provided that appropriate antecedents occur. Another viewpoint of the temperament concept reveals the premise that both

\footnotetext{
${ }^{4}$ Personal disposition called also a morphogenic trait is Allport's term for describing an individual feature. Yet, a trait means a mutual characteristic. A trait is a neuromental structure having the ability to provide many stimuli functionally equivalent and to initiate and direct equivalent (semantically cohesive) forms of adaptive and expressive behaviour (Allport 1961, p. 347). Personal disposition is a generalized neuromental structure (peculiar for a given person) having the ability to provide many stimuli functionally equivalent and to initiate and direct equivalent (semantically cohesive) forms of adaptive behaviour and stylistic one (Allport 1961, p. 373).
} 
temperament and personality refer to endogenous basic tendencies of behaviour, and that the distinction between these constructs is rather artificial (e.g. McCrae et al. 2000; Rothbart et al. 2000). Moreover, the temperament construct emerging from individual differences in perceptbased habits and skills is considered from the particular dimensions' perspective extensively developed in studies in that field (e.g. Ferrari and Vuletic 2010; Lerner et al. 1984; Rettew and McKee 2005; Rothbart et al. 2000; Zentner and Shiner 2012), strictly associated with the measurement tools divided into those allocated to children, adolescents, and adults. Referring to the temperament dimensions related to adults, the following selected measurement tools require attention: Thurstone Temperament Scale (Thurstone 1951); The Adult Temperament Questionnaire (ATQ) (Evans and Rothbart 2007) or Zuckerman-Kuhlman Personality Questionnaire (2000). Nonetheless, considering the paper's content and aims, Strelau and Zawadzki's (1993, 1995) Formal Characteristics of Behavior-Temperament Inventory (FCB-TI) as well as Cloninger's (1994a, 1994b, 1997; Cloninger et al. 1993) temperament (besides character) measurement tool are worth special attention.

The first one comprises six scales (each consists of 20 items) representing the temperament structure: (1) briskness (the tendency to react and perform activities quickly as well as to shift easily from one behaviour to another) - an exemplary item is 'Usually I work quickly, even if I have a lot of time', (2) perseverance (the tendency to continue and repeat behaviour after ceasing the stimuli) - an exemplary item is 'Sometimes I hum the same melody all day long', (3) sensory sensitivity (the ability to react to low stimulation sensory value) - an exemplary item is 'I see clouds flying through the night sky', (4) emotional reactivity (the tendency to react intensively to emotion-inducing stimuli) - an exemplary item is 'Slamming the door makes me nervous', (5) endurance (the ability to react adequately in situations demanding long-lasting or highly stimulating activity) - an exemplary item is 'I feel fresh and strong even after long journey', and (6) activity (the tendency to undertake behaviour of high stimulation value) - an exemplary item is 'I very often visit my friends'.

In turn, Cloninger's temperament measurement tool assumes four dimensions' assessment, namely, (1) novelty seeking (impulsive, exploratory, or sensation seeking behaviour) - an exemplary item is 'I often try new things just for fun or thrills, even if most people think it is a waste of time', (2) harm avoidance (inhibition of behaviour as the response to punishment signals) - an exemplary item is 'I am usually confident that everything will go well, even in situations that worry most people', (3) 
reward dependence (maintaining behaviour in response to cues of social reward) - an exemplary item is 'I like to please other people as much as I can', and (4) persistence (sustaining behaviour despite rare reinforcement) an exemplary item is 'I usually push myself harder than most people do because I want to do as well as I can'.

Since on the one hand temperament is defined as the way in which individuals behave and, on the other hand, it influences how individuals react to environmental stimuli and unfamiliar events as well as how they adjust to change (e.g. Dunning 2004; Kagan 2001), it justifies the assumption that the temperament construct has an impact on the character of the organizational strategy (behavioural strategy) in the context of endogenous development on the basis of seeking and using opportunities. Consequently, the following propositions have been formulated:

Proposition 7a (P7a): The high level of briskness, perseverance, sensory sensitivity, endurance, activity, novelty seeking, and persistence is positively associated with the capability of seeking and using opportunities in organizations.

Proposition $7 b$ (P7b): The high level of emotional reactivity, harm avoidance, and reward dependence is negatively associated with the capability of seeking and using opportunities in organizations.

Proposition 7c (P7c): The capability of seeking and using opportunities in organizations constitutes the mediating effect on the relationship between managerial temperamental dimensions, and organizational endogenous development.

The research methods most widely used in examining temperament are temperament assessment questionnaires, standardized and laboratory observations. The scale proposed to be incorporated is both Strelau and Zawadzki's (1993, 1995) Formal Characteristics of Behavior-Temperament Inventory (FCB-TI) and Cloninger's (1994a, 1994b, 1997; Cloninger et al. 1993) aforementioned.

Nevertheless, examining individual temperament is extremely complicated and, as a caveat, it is salient to keep in mind that extensive research on managerial temperament requires much more attention and a multi-disciplinary approach.

\section{Managerial character and organizational endogenous development.}

Contrary to the temperament concept, character is connected with both a behavioural code that helps an individual assess his/her activities and with the hallmarks stemming from environment. It involves individual differences in self-concepts about goals and values in functional relations to experience 
(Richter et al. 2004). Specifically, the distinction between temperament and character is assumed to be related to differences in major brain systems for procedural versus propositional learning (e.g. Richter et al. 2004). The temperament revealing the sensational core of personality refers to procedural memory. In turn, the character revealing the conceptual core of personality is related to propositional memory which includes high cognitive functions (Cloninger et al., 1993). Character, similarly to temperament, is epistemologically and methodologically considered in terms of dimensions. The most widely incorporated proposal of such dimensions simultaneously constituting the measurement tool is Cloninger's (e.g. 2004) scale being added to his temperament scale (together they constitute the so called Temperament and Character Inventory (TCI). Cloninger's character dimensions include: (1) self-directedness (the extent to which an individual is responsible, goal-oriented, and self-confident as well as the extent to which he/she identifies the self as an autonomous individual), cooperativeness (the extent to which individuals perceive themselves as integral parts of particular humanity), and (3) self-transcendence (the extent to which individuals perceive themselves as integral parts of the universe as a whole) - the dimension not exactly referring to the paper's research questions.

Self-directedness and cooperativeness seem to be associated with individualism and collectivism respectively despite subtle differences amongst the sub-categories of these constructs. Arguably, it justifies the assumption that character dimensions similar to individual social attitudes like individualism and collectivism on the one hand, and completing the understanding of temperament, on the other hand will influence the character of the organizational strategy (behavioural strategy) in the context of endogenous development on the basis of seeking and using opportunities. Consequently, the following propositions have been formulated:

Proposition 8a (P8a): The high level of self-directedness is positively associated with the capability of seeking and using opportunities in organizations.

Proposition 8b (P8b): The high level of cooperativeness is negatively associated with the capability of seeking and using opportunities in organizations.

Proposition 8c (P8c): The capability of seeking and using opportunities in organizations constitutes the mediating effect on the relationship between managerial character dimensions, and organizational endogenous development. 
According to the measurement tool, it is proposed to incorporate two of Cloninger's character dimensions, namely self-directedness (an exemplary item is: 'I have many bad habits that I wish I could break') and cooperativeness (an exemplary item is: 'I have no patience with people who don't accept my view').

Managerial resistance to risk and organizational stress resilience and organizational endogenous development.

Realizing strategic processes through seeking opportunities in the environment needs the tendency to take a risk which implies the necessity of organizational stress resilience and to work out an effective (for a given manager) style of coping with stress (compare Piórkowska 2014). The organizational stress concept constitutes a dynamic state in which an individual meets an opportunity, a limitation or a request connected with both individual desire and environmental demand (Schule 1980), as well as being linked to various theories of stress (e.g. Selye's systemic stress, Lazarus's psychological stress, or Hobfoll's resource theory). The temperamental characteristics may indicate individual tolerance of stress stimuli and mobilize individuals to act and counteract leading to managing stressful situations.

Coping with stress involves constantly changeable cognitive and behavioural efforts aiming at meeting the external and internal requirements assessed by an individual as burdening or exceeding his/her resources and abilities (e.g. Hobfoll 1998; Lazarus and Folkman 1984). These abilities are reflected with some dimensions (specified below as exemplary measurement tools). Thus, abilities to take risk through resisting stress and managing it in a proper way (using appropriate styles of coping with stress to particular situational cues) seem to determine the character of the organizational strategy (behavioural strategy) in the context of endogenous development on the basis of seeking and using opportunities. Consequently, the following propositions have been formulated:

Proposition 9a (P9a): The high level of confrontational coping, distancing, self-control, seeking social support, accepting responsibility, escape-avoidance, planned problem-solving, positive reappraisal, self-defence, stimulationpleasure, competitive striving, and self-improvement is positively associated with the capability of seeking and using opportunities in organizations.

Proposition 9b (P9b): The high level of acceptance-affiliation and approval-seeking is negatively associated with the capability of seeking and using opportunities in organizations. 
Proposition 9c (P9c): The capability of seeking and using opportunities in organizations constitutes the mediating effect on the relationship between managerial resistance to organizational stress and risk, and organizational endogenous development.

Selecting an appropriate measure is very difficult since the procedures typically used to establish the construct validity of the measures are incomplete and few studies have compared multiple coping measures using data from the same sample (Edwards and Baglioni 1993). However, it has been decided to propose two measurement tools. The first is the eight WCCL (The Ways of Coping Checklist) scales (Lazarus 1966; Lazarus and Folkman 1984; Lazarus and Launier 1978) representing (1) confrontational coping (six items) - an exemplary item: 'Took a big chance or did something very risky', (2) distancing (six items) - - an exemplary item: 'Went on as if nothing had happened', (3) self-control (seven items) - an exemplary item: 'Tried to keep my feelings to myself', (4) seeking social support (six items) - an exemplary item: 'Got professional help', (5) accepting responsibility (four items) - an exemplary item: 'Criticized or lectured myself', (6) escapeavoidance (eight items) - an exemplary item: 'Hoped a miracle would happen', (7) planned problem-solving (six items) - an exemplary item: 'Made a plan of action and followed it', and (8) positive reappraisal (seven items) - an exemplary item: 'Was inspired to do something creative'. The second one is Evart et al.'s (2002) Goal-Oriented Strivings in coping with stress consisting of six main categories (each with six items): (1) selfdefence (an exemplary item: 'Stop criticizing me'), (2) acceptance-affiliation (an exemplary item: 'Seek acceptance'), (3) approval-seeking (an exemplary item: 'Avoid disappointing others'), (4) stimulation-pleasure (an exemplary item: 'Seek to escape boredom'), (5) competitive striving (an exemplary item: 'Seek superior achievement'), and (6) self-improvement (an exemplary item: 'Improve skill').

\section{Managerial affective commitment and organizational endogenous development.}

The affective organizational commitment, on the one hand being an antecedent of inter alia turnover, job performance, absenteeism, tardiness, and organizational citizenship behaviour connected with a transgressive concept of human and, on the other hand, the consequence of heterostatic motivation, denotes an emotional attachment to, identification with, and involvement in the organization (e.g. Meyer et al. 2002).

Since on the one hand organizational commitment is a psychological link between an individual and an organization (e.g. Mathieu and Zajac 1990), on 
the other hand, managers with strong affective commitment remain with the organization and do their best in enhancing organization growth as they really want to do that (Allen and Meyer 1996), the affective organizational commitment constitutes the construct that link the described sociopsychological managerial characteristics determining the ability to realize strategic processes through seeking and using opportunities to endogenous development. Consequently, the following proposition has been formulated:

Proposition 10: Managerial affective commitment moderates the relationship between micro-foundations (in terms of socio-psychological characteristics) and organizational endogenous development simultaneously mediated by the managerial capabilities of seeking and using opportunities in organizations.

Considering the measurement tool, Affective Commitment Scale (with eight items) proposed by Meyer and Allen (Meyer and Allen 1997; Meyer et al. 1993) is to be incorporated. An exemplary item is: 'I would be very happy to spend the rest of my career with this organization'.

\section{Towards the conclusion of Section 3.}

The section emphasizes the impact of managerial characteristics on organizational endogenous development in the context of seeking and using opportunities. As a result, it contributes to developing the understanding of micro-foundations in the strategic management field. The general research

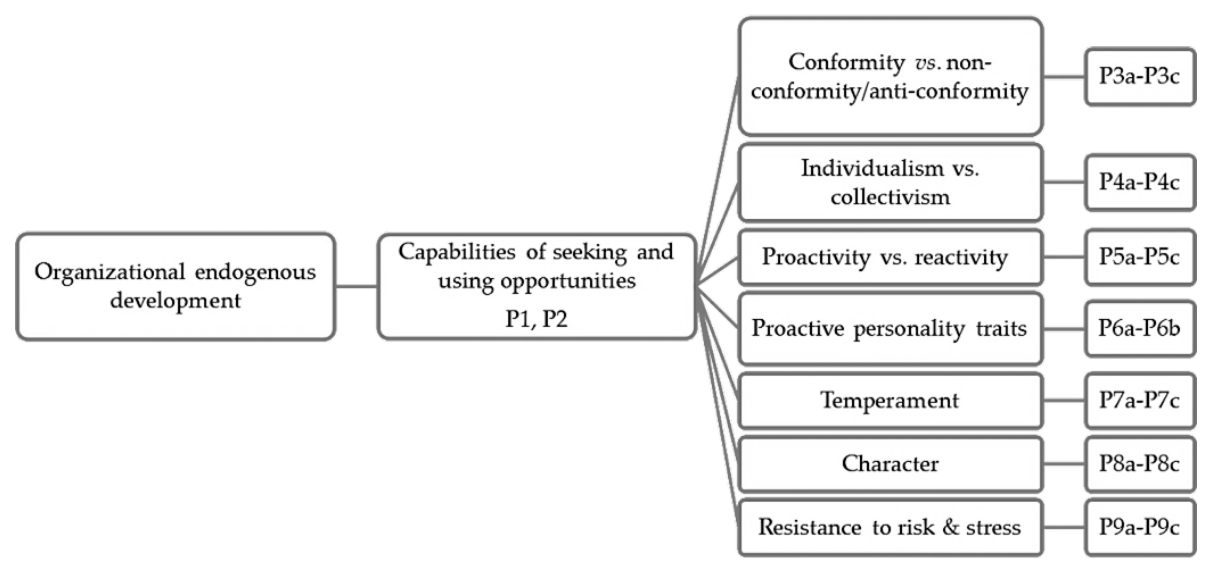

Figure 2. The general research framework based on the theoretical underpinnings

Source: own study (Piórkowska K.) strictly connected with realizing the own project financed by the National Scientific Centre in Poland on the basis of the decision no. DEC2012/05/D/HS4/01317. 
framework as a proposal based on the above theoretical underpinnings that includes antecedents (socio-psychological micro-predictors as independent variables) and correlates (capabilities of seeking and using opportunities as a mediator and affective organizational commitment as a moderator) of organizational endogenous development (a dependent variable) is presented in Figure 2. It is believed that, despite some limitations like the lack of knowledge whether considerations and ascertainment in the realm of the associations between the construct presented, or empirical investigation, the viewpoint and research idea emphasized will contribute to the more extensive bridging of the macro (organizational) - micro (individual) level research.

\section{CONCLUSION}

Organizational endogenous development from the perspective of microfoundations, opportunities and real options has been presented in the paper. Moving the perspective of considering strategic processes in that field from product-market categories to an enterprise's interior, the future directions of developing strategic management in terms of endogenous changes have been emphasized as well. With regard to the paper's aim and answering the research question no. 1: Is it possible to describe a strategy of contemporary organizations assuming their endogenous development?, it has been emphasized that enterprises can focus their strategic choices not only on product-market categories, but also on exogenous changes like opportunities (with supporting tools, e.g. real options approach). Moreover, the capability of seeking and using opportunities in organizations constitutes the mediating effect on the relationship mediating the relationship between managerial characteristics and organizational endogenous development which might contribute to an effective process of strategy formulation. Referring to the research question no. 2: What constitutes the fundamentals of organizational endogenous development?, it has been envisaged that managerial sociopsychological hallmarks constitute the primary fundamentals of organizational endogenous development. When it comes to the research question no. 3: How do those fundamentals affect organizational endogenous development?, the following propositions have been formulated: (a) The low level of conformity, the high level of both non-conformity and anti-conformity, an individualist managerial attitude, a proactive managerial attitude, the high level of proactive personality, the high level of briskness, perseverance, sensory sensitivity, endurance, activity, novelty seeking, and persistence, the high level of confrontational coping, distancing, self-control, seeking social support, accepting responsibility, escape-avoidance, planned problem-solving, 
positive reappraisal, self-defence, stimulation-pleasure, competitive striving, and self-improvement are positively associated with the capability of seeking and using opportunities in organizations; (b) A collectivist managerial attitude, a reactive managerial attitude, the high level of emotional reactivity, harm avoidance, and reward dependence, the high level of acceptanceaffiliation and approval-seeking are negatively associated with the capability of seeking and using opportunities in organizations; (c) Managerial affective commitment moderates the relationship between socio-psychological micropredictors and organizational endogenous development (see Figure 2).

It should be highlighted that the distinguished characteristics seem to be logically connected in terms of considerations constituting the theoretical underpinnings of the explored field. Nevertheless, empirical research has not been conducted in this area yet. This leads to the future research directions to further examine the triad of socio-psychological managerial characteristics (predictors, SMC), opportunities (O) and real options (RO), and its impact on organizational endogenous development. Additionally, it is expected to test the proposed operationalization of selected variables as well as to choose particular methods of testing. However, despite the limitations the paper's assumptions and the proposed research framework, it might constitute a starting point in exploring the phenomenon called organizational endogenous development.

\section{REFERENCES}

Ajzen, I., Attitudes, Personality, and Behaviour, $2^{\text {nd }}$ ed. Open University Press, England, 2005.

Allen, N., Meyer, J., Affective, Continuance, and Normative Commitment to the Organization: An Examination of Construct Validity, "Journal of Vocational Behavior", Vol. 49, pp. 252-276, 1996.

Allport, G. W., Pattern and Growth in Personality. Holt, Rinehart, Winston, New York, 1961. Allport, G. W., Personality: A Psychological Interpretation, Holt, New York, 1937.

Amram, M., Kulatilaka, N., Disciplined Decisions. Aligning Strategy with the Financial Markets, "Harvard Business Review", pp. 95-105, January-February 1999.

Ansoff, H. I., Managing Strategic Surprise by Response to Weak Signals, "Zeitschrift für betriebswirtschaftliche Forschung", no. 6, 1976.

Ansoff, H. I., Strategic Management. Palgrave Macmillan, 2007.

Ansoff, H. I., McDonnell, E., Implanting Strategic Management. Prentice Hall, New York, 1990.

Asch, S. E., An Experimental Investigation of Group Influence, [in:] Symposium on Preventive and Social Psychiatry. U.S. Government Printing Office, Washington, DC, 1957.

Asch, S. E., Effects of Group Pressure upon the Modification Distortion of Judgments, [in:] Guetzkow, H. (ed.), Groups, Leadership and Men. Carnegie Press, Pittsburgh, PA, 1951. 
Asch, S. E., Opinions and Social Pressures, "Scientific American”, Vol. 193(5), pp. 31-35, 1955.

Asch, S. E., Studies of Independence and Submission to Group Pressure: I. A Minority of One against a Unanimous Majority, "Psychological Monographs", 70 (9), No. 417, 1956.

Baer, M., Dirks, K. T., Nickerson, J. A., Microfoundations of Strategic Problem Formulation, "Strategic Management Journal", Vol. 34, pp. 197-214, 2013.

Bandura ,A., Social Learning Theory. Prentice-Hall, Englewood Cliffs, N. J., 1977.

Bateman, T. S., Crant, J. M., The Proactive Component of Organizational Behavior: A Measure and Correlates, "Journal of Organization Behavior", Vol. 14(2), pp. 103-118, 1993.

Boal, K. B., Hooijberg, R., Strategic Leadership Research: Moving on, "Leadership Quarterly", Vol. 11(4), pp. 515-549, 2001.

Bernberg, R. E., A Measure of Social Conformity, "Journal of Psychology”, Vol. 39, pp. 890896, 1955.

Bernberg, R. E., Personality Correlates of Social Conformity, "The Journal of Applied Psychology", Vol. 38, no. 3, 1954.

Bowman, E. H., Moskowitz, G. T., Real Options and Strategic Decision Making, “Organization Science”, Vol. 12, No. 6, November-December, pp. 772-777, 2001.

Bryant, P. T., Imprinting by Design: The Microfoundations of Entrepreneurial Adaptation, "Entrepreneurship. Theory and Practice", Vol. 38, Issue 5, pp. 1081-1102, 2014.

Buss, D. M., Selection, Evocation, and Manipulation, "Journal of Personality and Social Psychology", Vol. 53, pp. 1214-1221, 1987.

Campbell, A., The New Business Enlightenment, "Long Range Planning", Vol. 31, No. 1, pp. 147-149, 1998.

Cloninger, C. R., A Psychobiological Model of Personality and Psychopathology, "Journal of Psychosomatic Medicine", Vol. 2, pp. 91-102, 1997.

Cloninger, C. R., On Well-Being: Current Research Trends And Future Directions. Oxford University Press, New York, 2004.

Cloninger, C. R., Temperament and Personality, "Current Opinion in Neurobiology", 4/2, 1994a.

Cloninger, C. R., The Genetic Structure of Personality and Learning: A Phylogenetic Model, "Clinical Genetics", Vol. 1, pp. 124-137, 1994b.

Cloninger, C. R., Svrakic, D. M., Przybeck, T. R., A Psychobiological Model of Temperament and Character, "Archives of General Psychiatry", Vol. 50, pp. 975-990, 1993.

Cloninger, C. R., Svrakic, D. M., Integrative Psychobiological Approach to Psychiatric Assessment and Treatment, "Psychiatry", Vol. 60, pp. 120-141, 1997.

Collins, J. C., Porras, J. I., Built to Last: Successful Habits of Visionary Companies, $3^{\text {rd }}$ edition. Random House Business Books, London, 2000.

Copeland, T., Keenan, P. T., How Much is Flexibility Worth?, “The McKinsey Quarterly”, no. 2, pp. 38-49, 1998a.

Copeland, T., Keenan, P. T., Making Real Options Real, "The McKinsey Quarterly", no. 3, pp. 128-141, 1998b.

Crant, J. M., Proactive Behavior in Organizations, "Journal of Management", Vol. 26, pp. 435-462, 2000. 
Crant, J. M., The Proactive Personality Scale as a Predictor of Entrepreneurial Intentions, "Journal of Small Business Management", Vol. 34(3), pp. 42-49, 1996.

Deutsch, M., Gerard, H. B., A Study of Normative and Informational Social Influences upon Individual Judgment, "Journal of Abnormal and Social Psychology", 51, pp. 629-636, 1955.

Diener, E., Larsen, R. J., Emmons, R. A., Person Situation Interactions: Choice of Situations and Congruence Response Models, "Journal of Personality and Social Psychology, Vol. 47, pp. 580-592, 1984.

DuBrin, A. J., Proactive Personality and Behavior for Individual and Organizational Productivity. Edward Elgar, UK, Cheltenham, USA, MA Northampton, 2013.

Dunning, D., Quick Guide to the Four Temperaments and Change. Telos, California, 2004.

Duton, J. E., The Making of Organizational Opportunities: an Interpretive Pathway to Organizational Change, "Research in Organizational Behaviour", Vol. 15, pp. 195-226, 1993.

Edwards, J. R., Baglioni, A. J., The Measurement of Coping with Stress: Construct Validity of the Ways of Coping Checklist and the Cybernetic Coping Scale, "Work \& Stress", Vol. 7, no. 1, pp. 17-31, 1993.

Evans, D. E., Rothbart, M. K., Development of a Model for Adult Temperament, "Journal of Research in Personality", Vol. 41, pp. 868-888, 2007.

Evart, C. K., Jorgensen, R. S., Suchday, S., Chen, E., Matthews, K. A., Measuring Stress Resilience and Coping in Vulnerable Youth: The Social Competence Interview, "Psychological Assessment", Vol. 14, no. 3, pp. 339-352, 2002.

Farr, R., Attitudes, Social Representations and Social Attitudes, "Papers on Social Representations", 3(1), pp. 30-33, 1994.

Felin, T., Foss, N., Strategic Organization: A Field in Research of Micro-Foundations, "Strategic Organization", no. 3(4), pp. 441-455, 2005.

Felin, T., Foss N., The Endogenous Origins of Experience, Routines and Organizational Capabilities: The Poverty of Stimulus, "Journal of Institutional Economics", no. 7(2), pp. 231-256, June 2011.

Ferrari, M., Vuletic, L. (eds.), The Developmental Relations among Mind, Brain and Education. Springer, London, New York, 2010

Finkelstein, S., Hambrick, D. C., Strategic Leadership: Top Executives and Their Effects on Organizations. West Publishing Company, St. Paul, MN, 1996.

Gastil, R. D., The Determinants of Human Behavior, "American Anthropologist", New Series, Vol. 63, no. 6 (Dec.), pp. 1281-1291, 1961.

Gigerenzer, G., Selten, R. (eds.), Rethinking Rationality, Bounded Rationality. The Adaptive Toolbox, MIT Press, Cambridge, MA, 2002.

Goldsmith, R. E., Clark, R. A., Lafferty, B. A., Tendency to Conform: A New Measure and Its Relationship to Psychological reactance, "Psychological Reports", Vol. 96, pp. 591-594, 2005.

Grant, A. M., Ashford, S. J., The Dynamics of Proactivity at Work, "Research in Organizational Behavior", Vol. 28, pp. 3-34, 2008.

Greve, H. R., Microfoundations of Management: Behavioral Strategies and Levels of Rationality in Organizational Action, INSEAD, https://papers.ssrn.com/sol3/papers. cfm?abstract_id=2241332. 
Hall, C. S., Lindzey, G., Campbell, J. B., Theories of Personality, $4^{\text {th }}$ ed. Wiley, 1998.

Henzler, H., Functional Dogmas that Frustrate Strategy, The McKinsey Quarterly, Winter, pp. 23-35, 1982.

Higgins, E. T., Does Personality Provide Unique Explanations for Behaviour? Personality as Cross-Person Variability in General Principles, "European Journal of Personality", Vol. 14, pp. 391-406, 2000.

Hobfoll, S., There's More than Rugged Individualism in Coping. Part 2: Construct Validity and Further Model Testing "Anxiety, Stress and Coping”, Vol. 11, pp. 247-272, 1998.

Hornsey, M. J., Majkut, L., Terry, D. J., McKimmie, B. M., On Being Loud and Proud: Nonconformity and Counter-conformity to Group Norms, "British Journal of Social Psychology", Vol. 42(3), pp. 319-335, 2003.

Kagan, J., Temperament and the Reactions to Unfamiliarity, [in:] Gauvain, M., Cole, M., (eds.) Readings on the Development of Children, pp. 63-67. Worth Publisher, New York, 2001 .

Kahneman, D., Maps of Bounded Rationality: Psychology for Behavioural Economics, "The American Economic Review", 93 (5), pp. 1449-1475, 2003.

Kahneman, D., Thinking, Fast and Slow. Allen Lane, London, 2011.

Krupski, R., Planowany czy nie planowany rozwój matych firm. Co z teoriq zarzadzania strategicznego [The Planned or Unplanned Development of Small Enterprises], "Przegląd Organizacji” no 3, pp. 15-18, 2005a.

Krupski, R. (ed.), Zarzadzanie przedsiębiorstwem $w$ turbulentnym otoczeniu [Managing of an Enterprise in a Turbulent Environment]. PWE, Warsaw, 2005b.

Krupski, R., Elastyczność polskich przedsiębiorstw [The Flexibility of Polish Enterprises], "Przegląd Organizacji", no. 11, pp. 10-11, 2005c.

Krupski, R. Metody badania elastyczności [Methods of Flexibility Research] [in:] Jagoda, H., Lichtarski, J. (eds.) Nowe kierunki w zarzqdzaniu przedsiębiorstwem - celowość, skuteczność, efektywność [New Directions in Enterprise's Management - Efficacy, Effectiveness]. Research Papers of Wroclaw University of Economics in Wrocław, Wrocław, no. 1104, 2005d.

Krupski, R., Strategiczność zasobów [Strategy of Resources], "Przegląd Organizacji”, no. 9, pp. 7-8, 2006a.

Krupski, R., Badania nad oryginalnościq zasobów przedsiębiorstwa [Studies on Originality of an Enterprise's Recources] [in:] Skalik, J. (ed.) Zmiana warunkiem sukcesu. Dynamika zmian w organizacji - ewolucja czy rewolucja [Change as a Prerequisite for Success. The Dinamism of Changes in an Enterprise]. Research Papers of Akademia Ekonomiczna in Wrocław, no. 1141, Wrocław, pp. 97-105, 2006b.

Krupski, R., Elementy koncepcji zarzadzania okazja w organizacji [Elements of the Concept of Opportunity Management in an Enterprise] [in:] Dynamika zarzadzania organizacjami. Paradygmaty - metody - zastosowania [The Dinamism of Enterprises Management. Paradigms - Methods - Usage]. Research Papers of Akademia Ekonomiczna in Katowice, Katowice, pp. 95-106, 2007.

Krupski, R., Sus-Januchowska, A., Konfigurowanie scenariuszy [Configuration of Scenarios] [in:] Krzakiewicz, K. Instrumenty zarzadzania we wspótczesnym przedsiębiorstwie - 
nowe kierunki [Management Instruments in a Contemporary Enterprise - New Directions]. „Zeszyty Naukowe” 129, Wydawnictwo Uniwersytetu Ekonomicznego w Poznaniu, Poznań, pp. 311-318, 2009.

Langer, E .J., The Power of Mindful Learning. Addison-Wesley, Reading, M A, 1997.

Lazarus, R. S., Psychological Stress and the Coping Process. McGraw-Hill, New York, 1966.

Lazarus, R. S., Folkman, S., Stress, Appraisal and Coping. Springer, New York, 1984.

Lazarus, R. S., Launwr, R., Stress-related Transactions between Person and Environment, [in:] Pervin, A. L., Lewis, M. (eds.), Perspective in Interactional Psychology. Plenum, New York, 1978.

Lee, E., When and How Does Depersonalization Increase Conformity to Group Norms in Computer-mediated Communication?, "Communication Research", Vol. 33(6), pp. 423$-447,2006$.

Lee, E., Nass, C., Experimental Tests of Normative Group Influence and Representation Effects in Computer-mediated Communication: When Interacting via Computers Differs from Interacting with Computers, "Human Communication Research", Vol. 28(3), pp. 349-381, 2002.

Lerner, J. V., Chess, S., Lernerz, K., Early Temperament and Later Educational Outcomes, Paper presented at a Symposium at the Annual Meeting of the American Educational Research Association 68th, New Orleans, LA, April 23-27, 1984.

Leslie, K. J., Michaels, P. M., The Real Power of Real Options, "The McKinsey Quarterly", no. 3, pp. 5-22, 1997.

Levine, F. J., Feeling Strong: The Achievement of Authentic Power, "Journal of the American Psychoanalytic Association”, Vol. 52(1), pp. 541-551, 2004.

Lin, Z., Carley, K., Proactive or Reactive: An Analysis of the Effect of Agent Style on Organizational Decision-making Performance, "Intelligent Systems in Accounting, Finance and Management", Vol. 2, pp. 271-287, 1993.

Mankins, M. C., Steele, R. Stop Making Plans: Start Making Decisions, "Harvard Business Review", pp. 76-84, January 2006.

Martin, R. M., Whitehead's Categoreal Scheme and Other Papers. The Hague, Netherlands, 1974.

Mathieu, J. E., Zajac, D., A Review and Meta-analysis of the Antecedents, Correlates, and Consequences of Organizational Commitment, "Psychological Bulletin", Vol. 108, pp. 171-194, 1990.

McCrae, R. R., Costa, P. T., Jr, Ostendorf, F. et al., Nature over Nurture: Temperament, Personality, and Life Span Development, "Journal of Personality and Social Psychology", Vol. 78, pp. 173-186, 2000.

Meyer, J., Allen, N., Commitment in the Workplace: Theory, Research, and Application. Sage Publications, 1997.

Meyer, J., Allen, N., Smith, C., Commitment to Organizations and Occupations: Extension and Test of a Three-component Conceptualization, "Journal of Applied Psychology", Vol. 78, pp. 538-551, 1993.

Meyer, J., Stanley, D. J., Herscovitch, L., Topolnytsky, L., Affective, Continuance, and Normative Commitment to the Organization: A Meta-analysis of Antecedents, Correlates, and Consequences, "Journal of Vocational Behavior", Vol. 61, pp. 20-52, 2002. 
Miller, K. D., Waller, G., Scenarios, Real Options and Integrated Risk Management, "Long Range Planning" 36, pp. 93-107, 2003.

Munasib, A., Roy, D., Socializing Interactions and Social Attitude Formation, "Economics Working Paper Series", Oklahoma State University, 2008.

Myers, S. C., Determinants of Corporate Borrowing, "Journal of Financial Economics", Vol. 5, pp. 147-175, 1977.

Mun, J., Real Options Analysis. John Wiley \& Sons, Inc., USA, 2006.

Nooteboom, B., Stam, E., Micro-foundations for Innovation Policy. Amsterdam University Press, Amsterdam, 2008.

Obłój, K., Strategia organizacji [Organization's strategy]. PWE, Warsaw, 2007.

Obój, T., Obłój, K., Pratt, M. G., Dominant Logic and Entrepreneurial Firms' Performance in a Transition Economy, "Entrepreneurship Theory and Practice", Vol. 34 (1), pp. 151-170, 2010.

Parker, S. K., Williams, H. M., Turner, N., Modeling the Antecedents of Proactive Behavior at Work, "Journal of Applied Psychology", Vol. 91, no. 3, pp. 636-652, 2006.

Pervin, L. A., (eds.), Goal Concepts in Personality and Social Psychology, Hills-Dale, Erlbaum, 1989.

Piórkowska, K., Behavioral Strategies as Micro-foundations in Strategic Management, "Global Business and Economics Anthology", Vol. II, pp. 356-361, 2014.

Piórkowska, K., Behavioural Strategy. The Context of Mindfulness, "Przegląd Organizacji", no. 4, pp. 60-67, 2016b.

Piórkowska, K., Imponderabilia spoteczne $w$ kontekście behawioralnych strategii menedżerskich, [in:] Osobowościowe i kompetencyjne uwarunkowania sukcesu, Barabasz, A., Głuszek, E. (eds.), Research Papers of Wroclaw University of Economics, Wrocław, no. 273, 2012.

Piórkowska, K., Managing Occupational Stress as One of Endogenous Determinants of Manager's Loyalty, "Global Business and Economics Anthology”, Vol. I, pp. 178-189, 2014.

Piórkowska, K., Strategia behawioralna wyznacznikiem sukcesu organizacji?, „Zarządzanie i Finanse. Journal of Management and Finance”, Vol. 11, no. 4, part 2, pp. 321-329, 2013.

Piórkowska, K., Wybrane menedżerskie postawy społeczne w ujęciu dualnym [in:] Zasoby organizacji. Zagadnienia epistemologiczne i metodologiczne. pp. 193-209. Research Papers of Wroclaw University of Economics, no. 422, Wrocław, 2016a.

Piórkowska, K., Niemczyk, J., Managers' Decisions in the Context of Environmental Conditions and Behavioural Strategies, "Global Business and Economics Anthology" Vol. II, 2013.

Rampersad, H. K., Total Performance Scorecard: Een speurtocht naar zelf-kennis en competentie-ontwikkeling van lerende organisaties. Scriptum nanagement, Schiedam, The Netherlands, 2002.

Rettew, D. C., McKee, L., Temperament and Its Role in Developmental Psychopathology, "Harvard Review of Psychiatry", Vol. 13(1), pp. 14-27, 2005.

Richter, J., Brändström, S., Emami, H., Ghazonour, M., Temperament and Character in Cross-Cultural Comparisons between Swedish and Iranian People and Iranian Refugees 
in Sweden - Personality in Transition?, "Collective Antropology", Vol. 28, pp. 865-876, 2004.

Robbins, S., Coulter, M. K., Management, Pearson Education, Prentice Hall, 2005.

Rothbart, M. K., Ahadi, S. A., Evans, D. E., Temperament and Personality: Origins and Outcomes, "Journal of Personality and Social Psychology", Vol. 78, pp. 122-135, 2000.

Rudman, L. A., Fairchild, K., Reactions to Counterstereotypic Behavior: The Role of Backlash in Cultural Stereotype Maintenance, "Journal of Personality and Social Psychology", Vol. 87(2), pp. 157-176, 2004.

Sassenberg, K., Boos, M., Attitude Change in Computer-mediated Communication: Effects of Anonymity and Category Norms, "Group Processes and Intergroup Relations", Vol. 6(4), pp. 405-422, 2003.

Schuler, R. S., Definition and Conceptualization of Stress in Organizations. "Organizational Behavior and Human Performance", 1980.

Schwarzer, R., Proactive Coping Theory, Paper presented at the 20th International Conference of the Stress and Anxiety Research Society (STAR), Cracow, Poland, July 12-14, 1999.

Seibert, S. E., Crant, J. M., Kraimer, M. L., Proactive Personality and Career Success, "Journal of Applied Psychology", Vol. 84, pp. 416-427, 1999.

Sherif, M., A Study of Some Social Factors in Perception, "Archives of Psychology" 27, no. 187, pp. 1-60, 1935.

Siebert, J., Kunz, R., Developing and Validating the Multidimensional Proactive Decisionmaking Scale, "European Journal of Operational Research", Vol. 249, pp. 864-877, 2016.

Skat-Rørdam, P., Changing Strategic Direction. Copenhagen Business School Press, Copenhagen, 1999.

Stańczyk-Hugiet, E., An Evolutionary Approach to Strategic Dynamics, "Argumenta Oeconomica”, Vol. 1 (34), pp. 288-291, 2015.

Stańczyk-Hugiet, E., Piórkowska, K., Stańczyk, S., Intra-organizational Selection: Phenomenon and Its Behavioural and Cultural Determining Factors, "Journal of Management and Strategy", Vol. 6, no. 4, pp. 1-11, 2015.

Strelau, J., Zawadzki, B., The Formal Characteristic of Behavior - Temperament Inventory (FCB-TI): Theoretical Assumptions and Scale Construction, "European Journal of Personality", Vol. 7, pp. 313-336, 1993.

Strelau, J., Zawadzki, B., The Formal Characteristic of Behavior - Temperament Inventory (FCB-TI): Validity Studies, "European Journal of Personality", Vol. 9, pp. 207-229, 1995.

Sułkowski, Ł., Epistemology of Management. Peter Lang International, Frankfurt-BerlinBern-Vienna-Oxford-New York-London-Warsaw, 2013.

Sus, A., Strategic Planning on the Basis of Heuristic Forecasting [in:] Hittmár, S. (ed.), Theory of Management 6, The Selected Problems for the Development Support of Management Knowledge Base. Scientific Papers, Faculty of Management Science and Informatics, University of Zilina, Zilina, 2012.

Sus, A., The Real Options Approach - As the Modern Philosophy of Strategic Planning - the Results of Empirical Research, [in:] Hittmár, S. (ed.) Management Trends in Theory and 
Practice. Scientific Papers, EDIS, University Publishing House, University of Zilina, Zilina, 2013.

Thurstone, L. L., The Dimensions of Temperament, "Psychometrika", Vol. XVI, pp. 11-19, 1951.

Triandis, H. C., Cross-cultural Studies of Individualism and Collectivism, [in:] Berman, J. J. (ed.), Nebraska Symposium on Motivation 1989, Vol. 37, 1990.

Triandis, H. C., Individualism and Collectivism. Westview, Boulder, CO, 1995.

Triandis, H. C. (ed.), Motivation and Achievement in Collectivist and Individualist Cultures, Vol. 9. JAI Press Inc, Greenwich, CT, 1995a.

Triandis, H. C., Gelfland, M. J., Converging Measurement of Horizontal and Vertical Individualism and Collectivism, "Journal of Personality and Social Psychology", Vol. 74, pp. 118-128, 1998.

Triantis, A., Borison, A., Real Options: State of the Practice, "Journal of Applied Corporate Finance", Vol. 14 no. 2, Summer, pp. 8-24, 2001.

Trigeorgis, L., The Nature of Option Interactions and the Valuation of Investments with Multiple Real Options, "Journal of Financial and Quantitative Analysis", Vol. 28, No. 1, March, pp. 1-20, 1993.

Trigeorgis, L., Real Options. Managerial Flexibility and Strategy in Resource Allocation. The MIT Press Cambridge Massachusetts London, England, 1999.

VandenBos, G. R., APA Dictionary of Psychology, "American Psychological Association", Washington, 2007.

Wang, H., Barney, J. B., Reuer, J. J., Stimulating Firm-specific Investment through Risk Management, "Long Range Planning", 36, pp. 49-59, 2003.

Weick, K. E., Sutcliffe, K. M., Obstfeld, D. Organizing for High Reliability: Processes of Collective Mindfulness, [in:] Sutton, S. R., Staw, M. B. (eds.), Research in Organizational Behavior, Vol. 1, pp. 81-123. Jai Press, Stanford, 1999.

Weick, K. E., Sutcliffe, K. M., Managing the Unexpected. Jossey-Bass, San Francisco, 2001.

Weismann, M. M., Paykel, E. S., The Depressed Woman: A Study of Social Relationships. University of Chicago Press, Chicago, 1974.

Willis, R. H., Two Dimensions of Conformity-nonconformity, “Sociometry”, Vol. 26, pp. 499$-513,1963$.

Zeng, S., Zhang, S., Real Options Literature Review, "Scientific Research" "I-Business", 3, pp. 43-48, 2010.

Ziarkowski, R., Opcje rzeczowe oraz ich zastosowanie $w$ formułowaniu i ocenie projektów inwestycyjnych [Real Options and Their Usage in Formulating and Assessing Investment Projects]. Wydawnictwo Akademii Ekonomicznej w Katowicach, Katowice, 2004.

Zuckerman, M., Kuhlman, D. M., Personality and Risk-taking: Common Biosocial Factors, "Journal of Personality", Vol. 68, pp. 999-1029, 2000.

Received: August 2014, revised: October 2016

Acknowledgments: The paper is partially (as regards the section 'Socio-psychological managerial characteristics as the micro-foundations of organizational endogenous development') realized in the scope of the project that has been financed by the National Scientific Centre in Poland on the basis of the decision no. DEC-2012/05/D/HS4/01317. 